T. Turpeinen $\cdot$ T. Vanhala $\cdot$ E. Nevo $\cdot$ E. Nissilä

\title{
AFLP genetic polymorphism in wild barley (Hordeum spontaneum) populations in Israel
}

Published online: 23 April 2003

(C) Springer-Verlag 2003

\section{Theor Appl Genet (2002)}

DOI 10.1007/s00122-002-1151-6

The manuscript was received on 18 June 2002, not in 2001.

The online version of the original article can be found at http:// dx.doi.org/10.1007/s00122-002-1151-6

T. Turpeinen $(\bowtie)$

MTT Agrifood Research Finland, Plant Production Research,

Crops and Biotechnology, FIN-31600 Jokioinen, Finland

e-mail: timo.turpeinen@mtt.fi

Tel.: +358 3-4188-2538

Fax: +358 3-4188-2496

T. Vanhala

Laboratory of Plant Breeding, Department of Plant Sciences,

Wageningen University, P.O.Box 386, 6700 AJ Wageningen,

Netherlands

E. Nevo

Institute of Evolution, University of Haifa, Mt. Carmel,

Haifa 31905, Israel

E. Nissilä

Boreal Plant Breeding Ltd, FIN-31600 Jokioinen, Finland 